\title{
Multiple Mechanisms of Uranium Immobilization by Cellulomonas sp. Strain ES6
}

\author{
Vaideeswaran Sivaswamy, ${ }^{1,2}$ Maxim I. Boyanov, ${ }^{3}$ Brent M. Peyton, ${ }^{1,4}$ \\ Sridhar Viamajala, ${ }^{1,5}$ Robin Gerlach, ${ }^{4}$ William A. Apel, ${ }^{6}$ Rajesh K. Sani, ${ }^{1,7}$ \\ Alice Dohnalkova, ${ }^{8}$ Kenneth M. Kemner, ${ }^{3}$ Thomas Borch ${ }^{9}$ \\ ${ }^{1}$ Center for Multiphase Environmental Research and Department of Chemical Engineering, \\ Washington State University, Pullman, Washington \\ ${ }^{2}$ Research and Development, NLC Nalco India Ltd, Pune, India \\ ${ }^{3}$ Biosciences Division, Argonne National Laboratory, Argonne, Illinois \\ ${ }^{4}$ Center for Biofilm Engineering, Chemical and Biological Engineering, \\ Montana State University, Bozeman, Montana \\ ${ }^{5}$ Department of Chemical and Environmental Engineering, The University of Toledo, \\ Toledo, Ohio; telephone: +1-419-530-8094; fax: +1-419-530-8086; \\ e-mail: sridhar.viamajala@utoledo.edu \\ ${ }^{6}$ Biological Systems Department, Idaho National Laboratory, Idaho Falls, Idaho \\ ${ }^{7}$ Chemical and Biological Engineering Department, South Dakota School of Mines \& \\ Technology, Rapid City, South Dakota \\ ${ }^{8}$ Fundamental Sciences Department, Pacific Northwest National Laboratory, Richland, \\ Washington \\ ${ }^{9}$ Department of Soil and Crop Sciences, Colorado State University, Fort Collins, Colorado \\ Received 5 April 2010; revision received 4 September 2010; accepted 7 September 2010 \\ Published online 24 September 2010 in Wiley Online Library (wileyonlinelibrary.com). DOI 10.1002/bit.22956
}

\begin{abstract}
Removal of hexavalent uranium (U(VI)) from aqueous solution was studied using a Gram-positive facultative anaerobe, Cellulomonas sp. strain ES6, under anaerobic, non-growth conditions in bicarbonate and PIPES buffers. Inorganic phosphate was released by cells during the experiments providing ligands for formation of insoluble $\mathrm{U}(\mathrm{VI})$ phosphates. Phosphate release was most probably the result of anaerobic hydrolysis of intracellular polyphosphates accumulated by ES6 during aerobic growth. Microbial reduction of $\mathrm{U}(\mathrm{VI})$ to $\mathrm{U}(\mathrm{IV})$ was also observed. However, the relative magnitudes of $\mathrm{U}(\mathrm{VI})$ removal by abiotic (phosphate-based) precipitation and microbial reduction depended on the buffer chemistry. In bicarbonate buffer, X-ray absorption fine structure (XAFS) spectroscopy showed that $\mathrm{U}$ in the solid phase was present primarily as a non-uraninite U(IV) phase, whereas in PIPES buffer, $U$ precipitates consisted primarily of $\mathrm{U}(\mathrm{VI})$-phosphate. In both bicarbonate and PIPES buffer, net release of cellular phosphate was measured to be lower than that observed in
\end{abstract}

Correspondence to: S. Viamajala

Contract grant sponsor: U.S. Department of Energy, Office of Science, Environmental Management Science Program

Contract grant number: DE-FG02-03ER63582

Contract grant sponsor: DOE-NE Idaho Operations Office

Contract grant number: DE-AC07-05ID14517

Contract grant sponsor: Inland Northwest Research Alliance

Contract grant number: WSU 005
$\mathrm{U}$-free controls suggesting simultaneous precipitation of $\mathrm{U}$ and $\mathrm{PO}_{4}^{3-}$. In PIPES, U(VI) phosphates formed a significant portion of $U$ precipitates and mass balance estimates of $U$ and $\mathrm{P}$ along with XAFS data corroborate this hypothesis. High-resolution transmission electron microscopy (HRTEM) and energy dispersive X-ray spectroscopy (EDS) of samples from PIPES treatments indeed showed both extracellular and intracellular accumulation of $U$ solids with nanometer sized lath structures that contained $U$ and $P$. In bicarbonate, however, more phosphate was removed than required to stoichiometrically balance the $\mathrm{U}(\mathrm{VI}) / \mathrm{U}(\mathrm{IV})$ fraction determined by XAFS, suggesting that U(IV) precipitated together with phosphate in this system. When anthraquinone-2,6-disulfonate (AQDS), a known electron shuttle, was added to the experimental reactors, the dominant removal mechanism in both buffers was reduction to a non-uraninite $\mathrm{U}(\mathrm{IV})$ phase. Uranium immobilization by abiotic precipitation or microbial reduction has been extensively reported; however, the present work suggests that strain ES6 can remove U(VI) from solution simultaneously

Contract grant sponsor: National Science Foundation (NSF) (CAREER Award) Contract grant number: EAR 0847683

Contract grant sponsor: National Science Foundation-Earth Sciences

Contract grant number: EAR-0622171

Contract grant sponsor: Department of Energy-Geosciences

Contract grant number: DE-FG02-94ER14466

Additional supporting information may be found in the online version of this article 
through precipitation with phosphate ligands and microbial reduction, depending on the environmental conditions. Cellulomonadaceae are environmentally relevant subsurface bacteria and here, for the first time, the presence of multiple $\mathrm{U}$ immobilization mechanisms within one organism is reported using Cellulomonas sp. strain ES6.

Biotechnol. Bioeng. 2011;108: 264-276.

(C) 2010 Wiley Periodicals, Inc.

KEYWORDS: U(VI) reduction; Cellulomonas; U(VI)-phosphate; bioremediation; XAFS; U(IV)-phosphate

\section{Introduction}

Contamination of groundwater, soils and sediments by uranium (U) is a significant environmental problem (Borch et al., 2010). Sources of $U$ include natural deposits and cold war-era extraction and processing of $U$ ore (Anderson et al., 2003; Spear et al., 1999). A survey by Riley et al. (1992) showed that 11 of 18 U.S. Department of Energy (DOE) sites had $U$ contaminated soil and groundwater. Uranium at contaminated sites exists predominantly in two forms$\mathrm{U}(\mathrm{VI})$ and U(IV) (Bertsch et al., 1994). U(VI) is the most oxidized valence state (Emsley 1989), and in natural environments often forms aqueous complexes with high solubility and mobility in water. Reduction of U(VI) to $\mathrm{U}(\mathrm{IV})$ greatly decreases $U$ solubility and mobility in groundwater (Lovley et al., 1991).

Subsurface environments contaminated with radionuclides pose difficult remediation challenges. According to the National Research Council (2000), cleanup across the DOE complex is expected to cost at least $\$ 200$ billion and will take decades to complete. Physical/chemical methods to treat U-contaminated groundwater, including anion exchange, lime softening, conventional and activated alumina coagulation, and pump-and-treat, are expensive (Spear et al., 1999). An alternative to these technologies is the use of indigenous subsurface bacteria for immobilizing $\mathrm{U}$ in contaminated groundwater and soil (Borch et al., 2010; Merroun and Selenska-Pobell, 2008). Four basic mechanisms by which bacteria can immobilize $U$ are (1) microbially mediated reductive precipitation of $\mathrm{U}(\mathrm{VI})$ to $\mathrm{U}(\mathrm{IV})$, (2) $\mathrm{U}$ uptake and accumulation by cells, (3) adsorption onto cell surfaces, and (4) precipitation of $\mathrm{U}(\mathrm{VI})$ with inorganic phosphate released or produced by cells from the hydrolysis of phosphate containing compounds.

Cultures of Desulfovibrio desulfuricans, Desulfovibrio vulgaris, Geobacter metallireducens, Shewanella putrefaciens MR1, and Deinococcus radiodurans, among others have been demonstrated to reduce U(VI) to U(IV) (Fredrickson et al., 2000a,b; Gorby and Lovley, 1992; Lloyd et al., 2005; Lovley and Phillips, 1992; Spear et al., 2000; Suzuki and Banfield, 2004). Reduction of U(VI) can occur both directly by enzymatic action in the presence of an electron donor and indirectly by humic acid-mediated electron transfer $(\mathrm{Gu}$ et al., 2005). Cultures of Pseudomonas aeruginosa
(Strandberg et al., 1981), Bacillus subtilis (Fowle et al., 2000), and Chryseomonas MGF48 (Malekzadeh et al., 1998) can immobilize $U$ by cellular uptake. In some cases, $U$ chelates with intracellular polyphosphates and remains immobilized (Merroun et al., 2003, 2005). A third mechanism of $U$ immobilization is by adsorption onto cell surfaces. It has also been shown that Bacillus subtilis can immobilize $U$ through formation of uranyl-hydroxide, uranyl-carbonate, and calcium-uranyl-carbonate species with functional groups present on cell surfaces (Fowle et al., 2000; Gorman-Lewis et al., 2005). Finally, U immobilization can occur by precipitation with inorganic phosphate released by cells. Cultures of Citrobacter sp. (Yong and Macaskie, 1998), Acidithiobacillus ferrooxidans (Merroun et al., 2002), Bacillus sphaericus (Knopp et al., 2003), and Acinetobacter johnsonii (Boswell et al., 1999) have been demonstrated to remove uranium from water using a phosphate release mechanism. Under aerobic growth conditions, these microorganisms can accumulate phosphorus intracellularly in the form of polyphosphate (polyP) granules (Groenestijn et al., 1988; Tandoi et al., 1998). Under subsequent anaerobic conditions, the polyP granules are hydrolyzed to produce ATP while simultaneously releasing inorganic phosphate $\left(\mathrm{PO}_{4}^{3-}\right)$ from the cells (Groenestijn et al., 1987; Zafiri et al., 1999). In addition to hydrolysis of intracellular polyP, $\mathrm{PO}_{4}^{3-}$ can also be released by microbial metabolism of $\mathrm{P}$-containing substrates such as glycerol-3-phosphate. It has recently been demonstrated that naturally occurring bacterial isolates from the DOE Oak Ridge Field Research Center were capable of generating sufficient $\mathrm{PO}_{4}^{3-}$ through phosphatase activity to abiotically precipitate up to $95 \%$ of $\mathrm{U}(\mathrm{VI})$ in laboratory tests. This approach has been shown to be successful in removing $U(V I)$ through formation of autunite-like Uphosphate minerals under both aerobic and anaerobic, denitrifying conditions as well as at $\mathrm{pH}$ values as low as 5.0 (Beazley et al., 2007, 2009; Martinez et al., 2007).

Microbial release of $\mathrm{PO}_{4}^{3-}$ has been coupled to biologically induced precipitation of heavy metals or radionuclides (Boswell et al., 1998; Nakajima and Sakaguchi, 1986). Often, metal phosphates are highly insoluble and will precipitate on surfaces including cell walls (Macaskie et al., 1994; Montgomery et al., 1995). Solubility products of U(VI) phosphates as compiled by Palie (1970) range between $4.73 \times 10^{-47}$ and $2.14 \times 10^{-11}$. Natural immobilization of $U$ as $U(V I)$ phosphates occurs extensively at the Kongarra deposit in Australia (Duerden, 1990) and addition of phosphate minerals (e.g., hydroxyapatite) is reported to have reduced the solubility and bioavailability of $U$ in contaminated soils from the DOE Savannah River Site (Arey et al., 1999). The potential effectiveness of phosphatebearing, reactive barrier systems for $U$ removal from ground water has also been demonstrated (Fuller et al., 2002; Naftz et al., 2000). Jerden and Sinha (2003) reported that the low solubility of stable $\mathrm{U}(\mathrm{VI})$ phosphate minerals can limit $\mathrm{U}$ concentrations to less than $15 \mu \mathrm{g} / \mathrm{L}$ and phosphate-based strategies for in situ stabilization of $\mathrm{U}$ in oxidizing, fluid 
rich environments may be effective for long-term containment.

Strain ES6 is a Gram-positive isolate from subsurface cores obtained from the DOE Hanford site in Washington State. Sani et al. (2002) reported that Cellulomonas sp. removed $\mathrm{Cr}(\mathrm{VI})$ and $\mathrm{U}(\mathrm{VI})$ from solution under nongrowth conditions in the presence and absence of electron donor, and Borch et al. (2005) showed strain ES6 reduced nitroaromatics and ferrihydrite. Viamajala et al. (2007) showed that a majority of isolates enriched from Hanford cores contaminated with $\mathrm{Cr}$ and $\mathrm{U}$, and from uncontaminated overlying sediments, were Gram-positive facultative anaerobes in, or closely related to, the genus Cellulomonas. In addition, Viamajala et al. (2008) demonstrated the ability of ES6 to reduce $\mathrm{Cr}(\mathrm{VI})$ in continuous flow soil columns for prolonged periods without a continuous nutrient supply, indicating that Cellulomonas-like subsurface organisms could be stimulated to form stable biobarriers for longterm contaminant removal in the subsurface. Compared to Gram-negative bacteria, only a few Gram-positive organisms have been examined for remediation strategies through bio-immobilization. Thus, the study of metal transformations by Cellulomonas is environmentally relevant, particularly to the DOE Hanford site, and provides needed information on metal biotransformations by Gram-positive organisms. Results presented here show for the first time that a subsurface Cellulomonas sp. can simultaneously precipitate $U$ by release of cellular inorganic phosphate and by enzymatic reduction in the presence and absence of anthraquinone-2,6-disulfonate (AQDS).

\section{Materials and Methods}

\section{Culture Conditions}

Frozen stock cultures of Cellulomonas sp. ES6 $\left(-80^{\circ} \mathrm{C}\right.$ in $20 \%$ glycerol) were streaked on tryptic soy agar (TSA) and incubated aerobically at $30^{\circ} \mathrm{C}$ for 3 days. Sterile flasks containing tryptic soy broth (30 g/L; Difco, Sparks, MD) were inoculated with a single colony from the plate and were incubated at $30^{\circ} \mathrm{C}$ at $100 \mathrm{rpm}$ for 3 days to aerobically grow the cultures. These flasks provided the inocula for subsequent experiments.

\section{Preparation of Cells and Experimental Design}

All experiments were carried out with washed cells of a culture that had been grown as described above. Either bicarbonate buffer $(30 \mathrm{mM}, \mathrm{pH} 7 ; 1.3 \mathrm{mM} \mathrm{KCl})$ or Piperazine-1,4-bis(2-ethanesulfonic acid) (PIPES) buffer (30 mM, pH 7; $1.3 \mathrm{mM} \mathrm{KCl)} \mathrm{was} \mathrm{used} \mathrm{for} \mathrm{washing} \mathrm{and} \mathrm{re-}$ suspension. Cultures were centrifuged at 10,000 $\mathrm{g}$ for $20 \mathrm{~min}$. The supernatant was discarded and the cell pellets were resuspended in anaerobic bicarbonate or PIPES buffer with all transfers occurring in an anaerobic glove box $\left(\mathrm{N}_{2} / \mathrm{H}_{2} / \mathrm{CO}_{2}\right.$,
90:5:5). This process was performed three times and the cells were then re-suspended under non-growth conditions (defined here as the absence of exogenous nitrogen, phosphorus, vitamins, and other micronutrients) in sterile $\mathrm{KCl}(1.3 \mathrm{mM})$, with bicarbonate or PIPES buffer, and used for U precipitation experiments.

Anoxic conditions were obtained in the experimental medium containing bicarbonate and in the stock solution (1,000 $\mathrm{mg} / \mathrm{L})$ of $\mathrm{U}$ by bubbling with $\mathrm{N}_{2} / \mathrm{CO}_{2}$ (80:20) for $30 \mathrm{~min}$. The medium containing PIPES buffer was bubbled with ultrapure $\mathrm{N}_{2}$ for $30 \mathrm{~min}$. The final $\mathrm{pH}$ values of the media were 7.0. Aliquots of washed-cell suspensions were added to the buffered medium to give a total liquid volume of $20 \mathrm{~mL}$ (including cells, buffer, and U) contained in $25 \mathrm{~mL}$ serum bottles. Final cell concentrations in PIPES buffer experiments were $0.52 \mathrm{mg} / \mathrm{mL}$, while experiments in bicarbonate had either 1.15 or $2.3 \mathrm{mg}$-cells $/ \mathrm{mL}$. Cultures were incubated at room temperature $\left(25^{\circ} \mathrm{C}\right)$ and shaken at $75 \mathrm{rpm}$. Sodium bicarbonate, potassium chloride, and PIPES were obtained from Fisher (Pittsburgh, PA). Water for all experiments had a resistivity of $18.2 \mathrm{M} \Omega-\mathrm{cm}$ supplied from a Barnstead/Nanopure water system. For studies with AQDS, cells were re-suspended in autoclaved buffer solution containing $0.1 \mathrm{mM}$ AQDS (Fisher). Uranium was added as $\mathrm{UO}_{2} \mathrm{Cl}_{2} \cdot 3 \mathrm{H}_{2} \mathrm{O}$ (Bodman, Aston, PA) to reach either $0.1 \mathrm{mM}$ or $0.25 \mathrm{mM} \mathrm{U}$, depending upon the experiment. In addition to cell- and uranium-free controls, heat-killed cell controls were included. For heat-killed cell controls, aliquots of washed cell suspensions were transferred to anaerobic serum bottles in the glove box, sealed with butyl rubber septa, capped, crimped with aluminium seals and autoclaved. Anaerobic conditions in all treatments were verified by a resazurin indicator $(0.5 \mathrm{mg} / \mathrm{L})$ changing from pink to clear indicating an $E_{\mathrm{h}} \leq-51 \mathrm{mV}$ (Twigg, 1945). Abiotic controls served as indicators that aseptic conditions were maintained during the experiments. Culture purity was also checked by bright field microscopy (Model Leica DMLB, Leica Microsystems, Wetzlar, Germany) and by plating aliquots from individual treatment units on TSA. Samples were collected using disposable syringes, which were purged with $\mathrm{N}_{2}$ to avoid introducing $\mathrm{O}_{2}$ into the serum bottles.

Each set of experiments was carried out in duplicate and all critical treatments were repeated as separate experiments to ensure reproducibility. Data presented here are the average values and error bars represent the computed standard deviation between duplicates.

\section{Analytical Methods}

Dry cell weight analyses were performed at the start of the experiments by filtering $0.5 \mathrm{~mL}$ of sample through a preweighed $0.2 \mu \mathrm{m}$ Supor ${ }^{\circledR}$ membrane syringe filter (Gelman Acrodisc, Pall Corporation, Port Washington, NY). Samples from cell free controls were also filtered to ensure no change in weight due to the buffer itself. The filters were dried at $60^{\circ} \mathrm{C}$ for 3 days, until a constant weight was 
observed (Gerhardt et al., 1981). Removal of U(VI) from solution was evaluated by monitoring $\mathrm{U}(\mathrm{VI})$ concentration in filtered samples $(0.22 \mu \mathrm{m})$ withdrawn by syringe and needle and measured immediately as described previously (Sani et al., 2002). Filtered samples $(0.2 \mathrm{~mL})$ were diluted 1,000 or 4,000 times based on initial U(VI) concentration. Anoxic nanopure water was used to dilute the samples, and $1 \mathrm{~mL}$ of the diluted sample was mixed with $1.5 \mathrm{~mL}$ (according to instrument vendor recommendations) of Uraplex ${ }^{\mathrm{TM}} \mathrm{com}-$ plexing agent (Chemchek, Richland, WA). Samples were analyzed with a kinetic phosphorescence analyzer (Chemchek), which uses a pulsed nitrogen dye laser to specifically measure $\mathrm{U}(\mathrm{VI})$ concentrations in solution (Brina and Miller, 1992). Calibrations were performed using uranyl chloride solutions from 0 to $0.23 \mu \mathrm{M}$, yielding a $\mathrm{U}(\mathrm{VI})$ detection limit of $0.04 \mu \mathrm{M}$ with a precision of $\pm 5 \%$. Samples for inorganic phosphate analysis were withdrawn by syringe and needle and centrifuged at 10,000 $\mathrm{g}$ for $8 \mathrm{~min}$. Inorganic phosphate concentrations were determined on the supernatant spectrophotometrically using Phosver ${ }^{\circledR} 3$ Phosphate reagent (Hach, Loveland, CO) at $880 \mathrm{~nm}$ on a UV-vis spectrophotometer (Milton Roy Company Spectronic ${ }^{\mathbb{R}}$ GENESYS $5^{\mathrm{TM}}$, Rochester, NY). The minimum detectable phosphate concentration by this method is $0.2 \mu \mathrm{M}$.

\section{Transmission Electron Microscopy (TEM)}

The embedding procedure, as well as thin sectioning, was conducted in an anaerobic glove box $\left(\mathrm{Ar} / \mathrm{H}_{2}, 95: 5\right.$; Coy Laboratory Products, Inc., Grass Lakes, MI). Centrifuged Cellulomonas cells were briefly fixed $(1 \mathrm{~h})$ in $2.5 \%$ glutaraldehyde, and washed in anoxic nanopure water followed by a gradual ethanol dehydration series and infiltration in LR White embedding resin (London Resin Company, London, UK). Cured blocks were sectioned to $70 \mathrm{~nm}$ on an ultramicrotome (Leica Ultracut UCT), and sections were mounted on 200 mesh copper grids coated with formvar support film sputtered with carbon. Sections were examined using a JEOL 2010 high resolution transmission electron microscope (HR-TEM) equipped with a $\mathrm{LaB}_{6}$ filament operating at $200 \mathrm{kV}$ with a resolution of $0.19 \mathrm{~nm}$. Elemental analysis was performed using an Oxford Energy Dispersive Spectroscopy (EDS) system equipped with a SiLi detector coupled to the TEM, and spectra were analyzed with ISIS software (Oxford Instruments, Abingdon, UK). Images were digitally collected and analyzed using Digital Micrograph software (Gatan, Inc., Pleasanton, CA).

\section{X-Ray Absorption Spectroscopy}

X-ray absorption near-edge structure (XANES) and extended X-ray absorption fine structure (EXAFS) analyses were performed to determine the valence state and the average local environment of uranium in the solid phase. Filter paper with filtered residues (including cells and insoluble $\mathrm{U}$ ) were dried in an anaerobic glovebox and sealed between two pieces of Kapton ${ }^{\mathbb{R}}$ polyimide film to prevent oxidation while minimizing X-ray absorption (Borch et al., 2007). Samples were stored in the glovebox until analysis. XAFS data were collected on beamline 13-BM-C (GSECARS) at the Advanced Photon Source (APS). Energy selection was accomplished with a water-cooled $\mathrm{Si}(111)$ monochromator. Higher-order harmonics were eliminated by detuning the monochromator $\sim 10 \%$. The energy range studied was -150 to $+370 \mathrm{eV}$ (up to $9.8 \AA^{-1}$ ) about the $\mathrm{L}_{\text {III }}$ edge of $\mathrm{U}(17.166 \mathrm{keV})$. Incident and transmitted intensities were measured with in-line ionization chambers. Fluorescence spectra were recorded by monitoring the $\mathrm{U} \mathrm{L}_{\mathrm{III} \alpha}$ fluorescence with a 13-element $\mathrm{Ge}$ detector. The integrated peak intensities from 9 to 11 detector elements were averaged for 3-4 scans on each sample. Spectra from a uraninite and a uranyl nitrate standard were collected periodically in transmission. All spectra were collected at ambient temperature and pressure. Data were compared to spectra collected from well characterized samples at sector 10-ID (MR/Enviro-CAT) for previous projects (Burgos et al., 2008; Fletcher et al., 2010). The sector 10 -ID beamline undulator was tapered, and the incident energy was scanned using the $\mathrm{Si}(111)$ reflection of a liquid nitrogen cooled double-crystal monochromator in quickscanning mode (approximately $3 \mathrm{~min}$ per scan for the extended region and $40 \mathrm{~s}$ per scan for the near-edge region) (Segre et al., 2000). Energy calibration for sector 10-D measurements was maintained at all times by simultaneously collecting a spectrum from a hydrogen uranyl phosphate mineral using X-rays transmitted through the samples.

The spectra obtained from the uranyl nitrate standards at both beamlines were compared to account for energy resolution and energy calibration differences. The spectrum from beamline 10-ID was broadened and translated in energy until it coincided with the spectrum collected at beamline 13-BM-C. The same amount of broadening and translation was applied to all other data collected at sector 10-ID. Background subtraction for the spectra was performed using AUTOBK (Newville et al., 1993). The relative amounts of reduced and oxidized uranium were determined by linear combination analysis with the ATHENA software (Ravel and Newville, 2005). The uncertainty of the linear combination analysis is conservatively estimated at $10-15 \%$.

\section{Geochemical Modeling}

Geochemical Modeling was performed using Visual Minteq (Ver 2.61).

\section{Results and Discussion}

\section{U(VI) Precipitation Experiments in PIPES Buffer}

Figure 1a shows measured soluble inorganic phosphate concentrations over time in experiments performed with PIPES buffer at a cell concentration of $0.52 \mathrm{mg} / \mathrm{mL}$. Initially, 


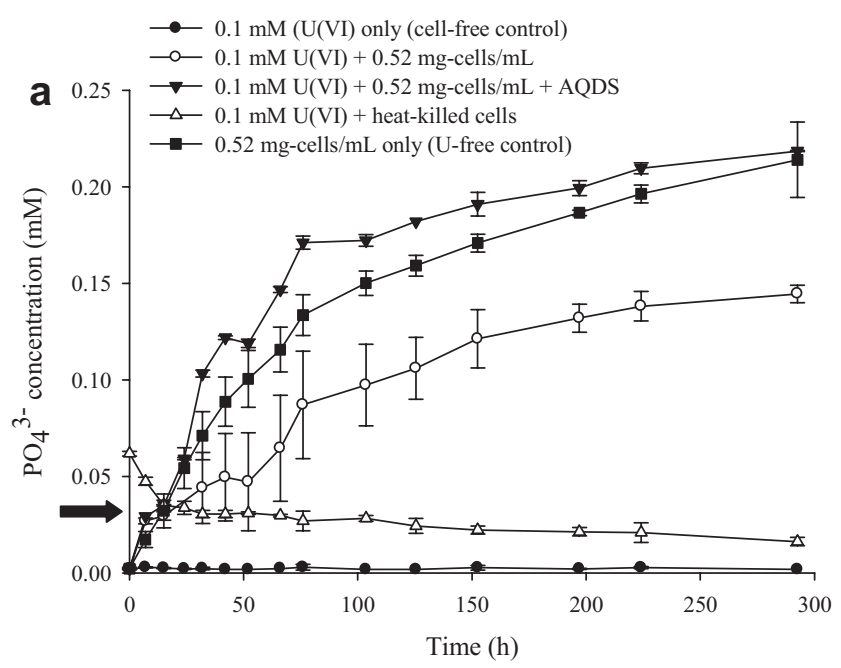

Like most other Gram-positive bacteria, the cell walls of Cellulomonas consist of secondary polymers, which often include teichoic acids and teichuronic acids, and contain phosphate and carboxylate residues, respectively (Panak et al., 2000). The initial amount of phosphate observed in heat-killed cells is likely from these polymers, nucleic acids, and other phosphate rich cellular components that may have been released during autoclaving.

Figure $1 \mathrm{~b}$ shows soluble $\mathrm{U}(\mathrm{VI})$ concentrations measured during the anaerobic, non-growth experiments in PIPES buffer with cell suspensions and cell-free controls. Since spontaneous precipitation of $\mathrm{U}(\mathrm{VI})$, as metaschoepite, occurs in PIPES buffer for U(VI) concentrations greater than $0.125 \mathrm{mM}$ (Fredrickson et al., 2000b), only $0.1 \mathrm{mM}$ $\mathrm{U}(\mathrm{VI})$ was used in these studies. In all treatments containing cells, including the heat-killed cell control, soluble $\mathrm{U}(\mathrm{VI})$ concentrations decreased over time. No change in soluble $\mathrm{U}(\mathrm{VI})$ concentration was observed in cell-free controls. In the treatment with heat-killed cells, the decrease in $\mathrm{U}(\mathrm{VI})$ concentration occurred immediately after inoculation, while with viable cells there was a lag period preceding soluble $\mathrm{U}(\mathrm{VI})$ removal in AQDS-free treatments (approximately $14 \mathrm{~h}$, shown by arrow in Fig. 1b). AQDS-containing treatments showed a fairly rapid decrease in $\mathrm{U}(\mathrm{VI})$ concentrations. The immediate onset of $\mathrm{U}(\mathrm{VI})$-precipitation with heat-killed cells was likely caused by readily available dissolved phosphate released from cells due to heat-induced lysis, although adsorption to lysed cell surfaces is also possible (Gorman-Lewis et al., 2005). As there are likely no active enzymes in autoclaved cells, phosphate concentration did not increase above the initial value and $\mathrm{U}(\mathrm{VI})$ precipitation started immediately after addition into solution. In treatments with viable cells, phosphate concentrations were initially below measurable values, but increased with time (Fig. 1a). However, the onset of U(VI) precipitation in these treatments appears to have been delayed for at least $14 \mathrm{~h}$ (data point indicated by arrow in Fig. 1b). The phosphate concentration at $14 \mathrm{~h}$ in all tests with viable cells was $0.029 \pm 0.002 \mathrm{mM}$ (arrow on Fig. 1a). Experiments performed at lower cell concentrations $(0.26 \mathrm{mg}-\mathrm{ES} 6 / \mathrm{mL})$ as well as other abiotic tests (data not shown) showed that precipitation of $0.1 \mathrm{mM} \mathrm{U}(\mathrm{VI})$ in PIPES did not occur below a phosphate concentration of $0.03 \pm 0.01 \mathrm{mM}$. Similar results were observed with Citrobacter sp. and the delay in onset of phosphate-mediated uranyl removal was attributed to the solubility product and the time required for the formation of nucleation sites (Yong and Macaskie, 1995). in phosphate concentration over time. In the absence of AQDS, the increase in phosphate was less than in the corresponding treatments that did not contain $\mathrm{U}(\mathrm{VI})$. In the presence of AQDS, added as a humic acid analog, approximately the same amount of phosphate was released in the $\mathrm{U}(\mathrm{VI})$-containing treatments as in the $\mathrm{U}(\mathrm{VI})$-free treatments (statistically verified at $P=0.05$ ). With heatkilled cells there was a measurable initial phosphate concentration, which decreased with time as U precipitated.

\section{U(VI) Precipitation Experiments in Bicarbonate Buffer}

Similar to tests in PIPES buffer, experiments were also performed under non-growth conditions in bicarbonate buffer. To keep the duration of study similar to the experiments in PIPES buffer, higher cell concentrations $(1.15$ and $2.3 \mathrm{mg}$-cells $/ \mathrm{mL})$ were used since preliminary 

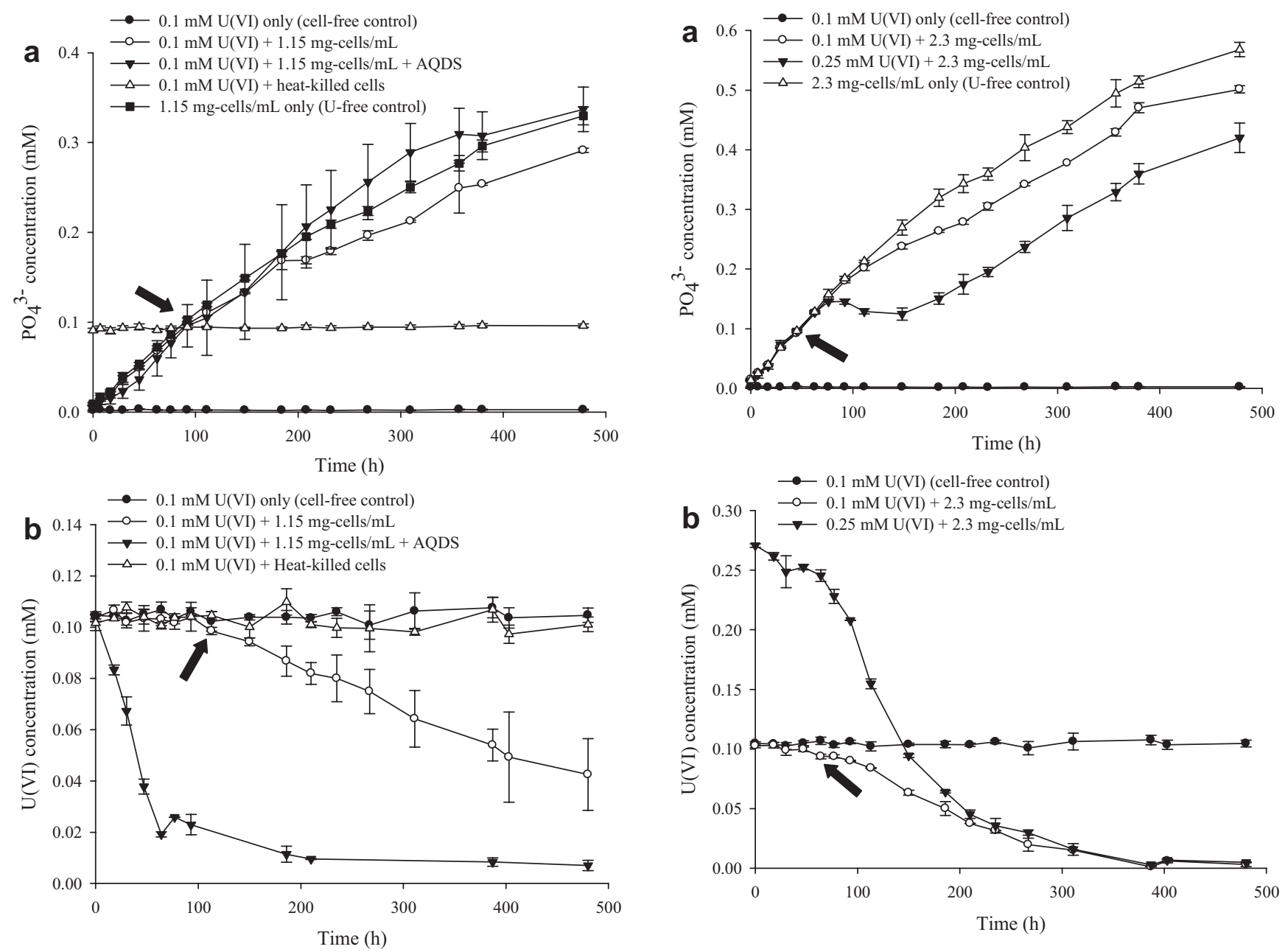

Figure 2. Measured concentrations of (a) soluble inorganic phosphate, and (b) soluble $\mathrm{U}(\mathrm{VI})$ over time for experiments performed with ES6 cultures $(1.15 \mathrm{mg}$-cells $/ \mathrm{mL}$ ) re-suspended in bicarbonate buffer ( $\mathrm{pH} 7)$. Data for cell-free, U-free, and heat-killed cell controls are also shown. Error bars represent one standard deviation from mean values. Arrows on ( $a$ and $b$ ) indicate the first sample showing measurable U(VI) removal in treatments containing active ES6 cultures.

results showed that $\mathrm{U}(\mathrm{VI})$ removal occurred at a much slower rate in the bicarbonate buffered systems compared to PIPES. Figures $2 \mathrm{a}$ and $3 \mathrm{a}$ show phosphate release by ES6 at the two cell concentrations in the presence and absence of $\mathrm{U}(\mathrm{VI})$. As observed during experiments in PIPES buffer, phosphate concentrations increased over time in all bicarbonate buffer experiments containing viable cells. Heat-killed controls, while containing measurable phosphate at the start of the experiments, did not show an increase in phosphate over time (Fig. 2a).

Similar to treatments in PIPES buffer, viable cells in bicarbonate buffer continuously removed $\mathrm{U}(\mathrm{VI})$ from solution after sufficient release of phosphate. Figures $2 \mathrm{~b}$ and $3 \mathrm{~b}$ show the observed changes in concentrations of soluble U(VI) over time for cell suspensions and cell-free controls under non-growth anaerobic conditions in

bicarbonate buffer. No change in soluble U(VI) concentration was observed in cell-free controls or in the heat-killed cell control. In heat-killed controls, active enzymes responsible for phosphate release were likely denatured and the initial phosphate concentration was insufficient to initiate $\mathrm{U}$ precipitation. Adsorption was also likely more difficult due to formation of stable uranyl-carbonato complexes; so no decrease in soluble U(VI) concentration was measured.

$\mathrm{U}(\mathrm{VI})$ removal from solution occurred more slowly in the bicarbonate buffer experiments compared to the PIPES buffer experiments despite the higher cell and phosphate concentrations. These results are consistent with previous observations of slower precipitation or adsorption of $\mathrm{U}(\mathrm{VI})$ in systems containing bicarbonate due to formation of uranyl-carbonato complexes (Kim et al., 2009; Stewart et al., 
2010). It is interesting to note that at high cell loadings the onset of rapid removal of $\mathrm{U}(\mathrm{VI})$ corresponds closely with the lowering of the measured rate of increase in soluble $\mathrm{PO}_{4}^{3-}$; both phenomena occur between 100 and $250 \mathrm{~h}$ (Fig. 3). This behavior is consistent with the formation of $\mathrm{U}(\mathrm{VI})$ phosphates during this period, resulting in lower soluble phosphate concentrations in treatments containing $\mathrm{U}(\mathrm{VI})$, relative to $\mathrm{U}$-free controls. However, these results would also not be inconsistent with reduction of $\mathrm{U}(\mathrm{VI})$ to $\mathrm{U}(\mathrm{IV})$ and precipitation of U(IV)-phosphate as suggested by Khijniak et al. (2005) and Fletcher et al. (2010) in studies with Grampositive Thermoterrabacterium ferrireducens and Desulfitobacterium spp., respectively that were also performed in bicarbonate buffered media. In AQDS-free treatments, $\mathrm{U}(\mathrm{VI})$ concentrations did not decrease until approximately $0.1 \mathrm{mM}$ of $\mathrm{PO}_{4}^{3-}$ were detected in solution (as indicated by arrows in Figs. 2 and 3). U(VI) removal was not observed in heat killed controls although phosphate was present at a concentration of just below $0.1 \mathrm{mM}$ (Fig. 2). The AQDS containing treatments while showing the fastest $\mathrm{U}(\mathrm{VI})$ removal from solution in bicarbonate buffered treatments (Fig. 2) removed $\mathrm{U}(\mathrm{VI})$ more slowly than the PIPES buffer treatments (Fig. 1) despite an approximately two-fold higher cell concentration.

Visual Minteq-based equilibrium speciation modeling indicated that the presence of $30 \mathrm{mM}$ carbonate results in the formation of uranyl-carbonato complexes such as $\mathrm{UO}_{2}\left(\mathrm{CO}_{3}\right)_{2(\mathrm{aq})}^{2-}$ and $\mathrm{UO}_{2}\left(\mathrm{CO}_{3}\right)_{3(\mathrm{aq})}^{4-}$, and $\mathrm{UO}_{2} \mathrm{CO}_{3(\mathrm{aq})}^{0}$ while uranyl-hydroxo and -phosphate species dominated the PIPES buffered systems. Similar predictions were made by Fredrickson et al. (2000b). Even at the phosphate concentrations observed in the heat-killed cell treatments $\left(0.1 \mathrm{mM} \mathrm{PO}_{4}^{3-}\right)$, Minteq did not predict any uranylphosphate species, which agrees with the constant phosphate and $\mathrm{U}(\mathrm{VI})$ concentration observed in the heat-killed control treatments (Fig. 2).

\section{Effects of AODS on Phosphate Release and U(VI) Removal}

A soil component that can significantly influence the mobility of metals is naturally occurring organic matter, such as humic materials. Humic substances are heterogeneous high-molecular-weight organic materials, widely distributed on the earth's surface (Benz et al., 1998) and often thermodynamically stable in the subsurface (Watts, 1997). In addition, humic materials can function as catalysts for bacterial metal reduction. Lovley et al. $(1996,1998)$ reported that microorganisms can donate electrons to humic acids, which can shuttle electrons between microbes and $\mathrm{Fe}(\mathrm{III})$ oxide, and that relatively low concentrations of humic substances are sufficient to facilitate $\mathrm{Fe}(\mathrm{III})$ reduction. AQDS (2,6-anthraquinone disulfonate) has been proposed as a model compound for quinone moieties in humics that can catalyze microbial reduction of $\mathrm{Cr}(\mathrm{VI})$, $\mathrm{U}(\mathrm{VI}), \mathrm{Fe}(\mathrm{III})$, and $\mathrm{Mn}(\mathrm{IV})$ (Fredrickson et al., 2000a,b;
Gounot, 1994; Lovley et al., 1996). Previous studies showed that ES6 can enzymatically reduce AQDS and can facilitate reduction of $\mathrm{Cr}(\mathrm{VI}), \mathrm{Fe}(\mathrm{III})$ (Viamajala et al., 2008) and nitroaromatics such as 2,4,6-trinitrotoluene (Borch et al., 2005). Because of the ubiquitous nature of humic substances in the subsurface, it is important to understand the relative contributions of both, direct microbial processes and indirect mechanisms, through electron shuttling compounds on soluble $\mathrm{U}(\mathrm{VI})$ removal.

Experiments with viable ES6 cells were performed in PIPES and bicarbonate buffer in the presence of $0.1 \mathrm{mM}$ AQDS and $0.1 \mathrm{mM} \mathrm{U}(\mathrm{VI})$. During these experiments, the media turned yellow indicating the reduction of AQDS by ES6, and a continuous decrease in soluble U(VI) concentration was observed (Figs. $1 \mathrm{~b}$ and $2 \mathrm{~b}$ ). The phosphate concentrations measured at the end of the experiments in AQDS containing treatments were nearly equal to the measured values in U-free controls $(t=295 \mathrm{~h}$ in Fig. 1a and $t=480 \mathrm{~h}$ in Fig. 2a). These observations suggest that phosphate-mediated precipitation was likely not a major mechanism contributing to $\mathrm{U}(\mathrm{VI})$ removal in treatments containing AQDS and that $\mathrm{U}(\mathrm{VI})$ reduction to $\mathrm{U}(\mathrm{IV})$ was probably responsible for a significant fraction of the observed decrease in soluble $\mathrm{U}(\mathrm{VI})$.

In both buffers, the presence of AQDS enhanced rates of $\mathrm{U}(\mathrm{VI})$ removal in comparison with experiments performed in its absence-an effect that was slightly more pronounced in bicarbonate (Fig. 2b) than in PIPES (Fig. 1b). However, the overall specific $U(V I)$ removal rates (when normalized to biomass concentrations) in the presence of AQDS were much higher in PIPES (average initial rate $=0.005 \mathrm{mmol} / \mathrm{h} /$ mg-cells) than in bicarbonate (average initial rate$=0.001 \mathrm{mmol} / \mathrm{h} / \mathrm{mg}$-cells). As discussed earlier, $\mathrm{UO}_{2(\mathrm{aq})}^{2+}$ forms a series of stable aqueous complexes $\left[\mathrm{UO}_{2}\left(\mathrm{CO}_{3}\right)_{3(\mathrm{aq})}^{4(\mathrm{aq})}\right.$, $\mathrm{UO}_{2}\left(\mathrm{CO}_{3}\right)_{2 \text { (aq) }}^{2-}$, and $\left.\mathrm{UO}_{2} \mathrm{CO}_{3(\mathrm{aq})}^{0}\right]$ in bicarbonate buffer, whereas speciation in PIPES buffer is dominated by hydroxo complexes such as $\mathrm{UO}_{2} \mathrm{OH}_{(\mathrm{aq})}^{+}$or $\mathrm{UO}_{2}(\mathrm{OH})_{2(\mathrm{aq})}^{0}$ (Fredrickson et al., 2000b). $\mathrm{UO}_{2}(\mathrm{OH})_{2(\mathrm{aq})}^{0}$ reduction is accompanied by a greater change in free energy than reduction of uranyl-carbonato complexes and is therefore favored (Fredrickson et al., 2000b; Scott and Morgan, 1990; Zehnder and Stumm, 1988).

\section{Characterization of ES6 Mediated U Precipitates}

\section{XANES spectra}

Figure 4 shows XANES spectra from samples of ES6 reacted with $\mathrm{U}(\mathrm{VI})$ under four different conditions (PIPES or bicarbonate buffer, \pm AQDS). The samples were collected at the end of the experimental run. Spectra are compared to $\mathrm{U}(\mathrm{IV})$ and $\mathrm{U}(\mathrm{VI})$ endmembers. For U(VI), an autunite precipitate verified by $\mathrm{X}$-ray diffraction was used; for $\mathrm{U}(\mathrm{IV})$, a previously characterized, fully-reduced mononuclear $\mathrm{U}(\mathrm{IV})$ phase was used (Fletcher et al., 2010). The comparisons show that in the absence of AQDS, $U$ is 


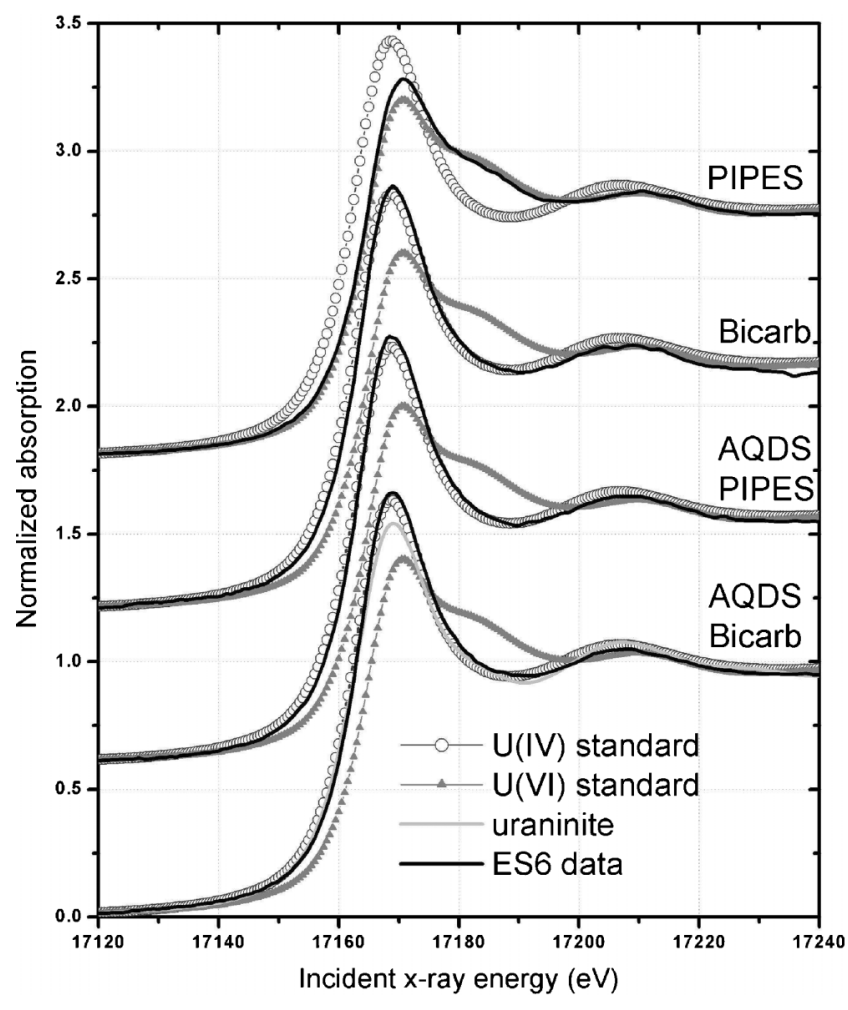

Figure 4. XANES data from U(VI) reacted with ES6 under different solution conditions (lines), compared to the U(VI) and U(IV) standards (symbols). The light gray line in the bottom graph shows the XANES spectrum of polycrystalline uraninite.

predominantly oxidized U(VI) in the PIPES buffer ES6 sample, whereas $U$ is predominantly reduced in the bicarbonate buffer ES6 sample. In the presence of AQDS, $U$ is predominantly reduced to $U(I V)$ in both bicarbonate and PIPES systems. Linear combination analysis to quantify $\mathrm{U}(\mathrm{IV}) / \mathrm{U}(\mathrm{VI})$ ratios was not performed for the XANES data because possible small monochromator shifts during the measurement could not be excluded (spectra from standards were not collected simultaneously with the data). The $\mathrm{U}(\mathrm{IV}) / \mathrm{U}(\mathrm{VI})$ ratios were estimated instead from fits of the EXAFS data, which are less susceptible to energy axis shifts.

\section{EXAFS spectra}

Figures $5 \mathrm{~A}$ and $6 \mathrm{~A}$ demonstrate significant similarity between the EXAFS data from the ES6-PIPES buffer sample and an abiotic autunite precipitate (U(VI)-phosphate), indicating that $\mathrm{U}$ was sequestered predominantly as uranyl phosphate in this system. The smaller amplitude of the EXAFS signal in the ES6-PIPES system relative to the standard is likely due to the presence of small amounts of reduced $\mathrm{U}(\mathrm{IV})$, which was estimated at about $15 \%$ of total $\mathrm{U}$ by linear combination (LC) analysis. The EXAFS spectrum from the ES6-bicarbonate buffer sample appears very similar to the reduced $\mathrm{U}(\mathrm{IV})$ endmember (black line on

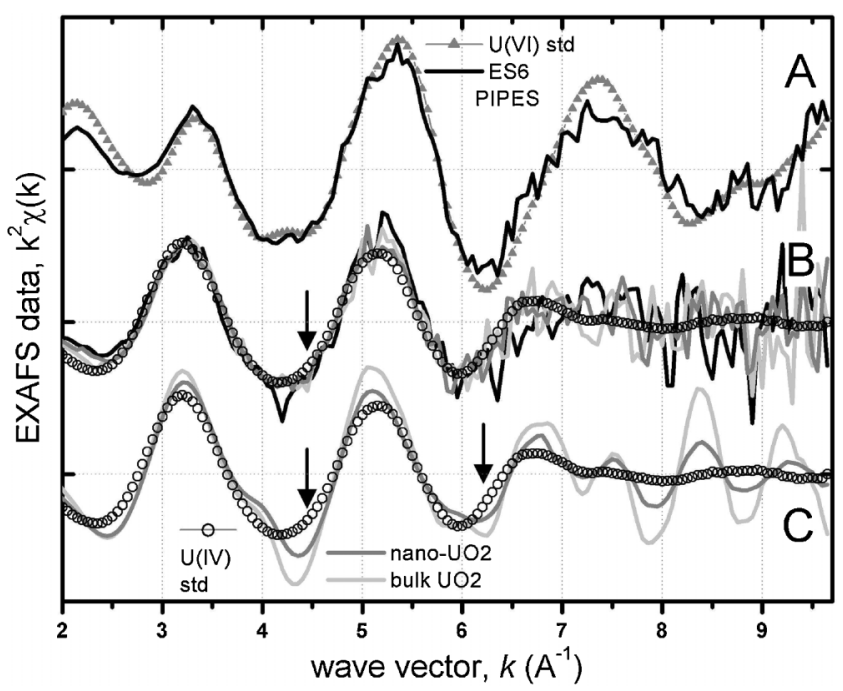

Figure 5. U L(III)-edge EXAFS data from Cellulomonas ES6 samples, compared to $\mathrm{U}(\mathrm{VI})$ and $\mathrm{U}(\mathrm{IV})$ standards. A: ES6 in PIPES/no AODS buffer (line) compared to an autunite (U(VI)-P04) precipitate (symbols). B: ES6 in bicarbonate/no AODS buffer (black line) and in bicarbonate or PIPES buffer with AODS (gray lines). Symbols: mononuclear U(IV) phase from Fletcher et al. (2010). C: U(IV) standards: bulk uraninite (light gray), nanoparticulate uraninite from Burgos et al. (2008) (dark gray), and mononuclear U(IV) from Fletcher et al. (2010) (symbols).

Figs. $5 \mathrm{~B}$ and $6 \mathrm{~B}$ ). The Fourier transform of the data reveals the presence of a uranyl component in the spectrum, suggested by the intermediate position of the $1-2 \AA$ peak between the $U(I V)$ and $U(V I)$ endmember on Figure $5 B$. The $\mathrm{U}(\mathrm{IV}) / \mathrm{U}(\mathrm{VI})$ ratio in this sample was quantified as approximately 70:30 in this sample by LC analysis of the EXAFS data.

In the presence of AQDS, the EXAFS spectra from samples in both PIPES and bicarbonate buffer resemble significantly the mononuclear U(IV) phase obtained in a previous study (Fletcher et al., 2010) (gray lines and symbols on Fig. 5B). Although the noise level in the spectra is high at larger $k$ values, the spectra are of good quality below $7 \AA^{-1}$ and do not show features characteristic of the nanoparticulate or polycrystalline uraninite standards (arrows on Fig. 5C). The Fourier transform (FT) of the ES6 + AQDS spectra are compared to mononuclear U(IV), nanoparticulate uraninite, and bulk uraninite on Figure 6C. The FT peak around $R+\Delta=1.6 \AA$ (U-O) is nearly identical in position and amplitude to that of the fully reduced, mononuclear U(IV) standard, confirming complete reduction to $\mathrm{U}(\mathrm{IV})$ in the ES6 + AQDS samples. The FT peak around $R+\Delta=3.6 \AA$ (vertical line) is due to the bidentate bond between two $\mathrm{U}$ atoms in uraninite. A 40-50\% decrease in its amplitude relative to uraninite suggests the presence of nanoparticulate uraninite with average particle size of 2$5 \mathrm{~nm}$ (e.g., Boyanov et al., 2007; Burgos et al., 2008; Suzuki et al., 2002). The spectra from U(IV) reduced by ES6 in the presence of AQDS show a very small amplitude of the U-U peak, much smaller than the spectrum of nanoparticulate 


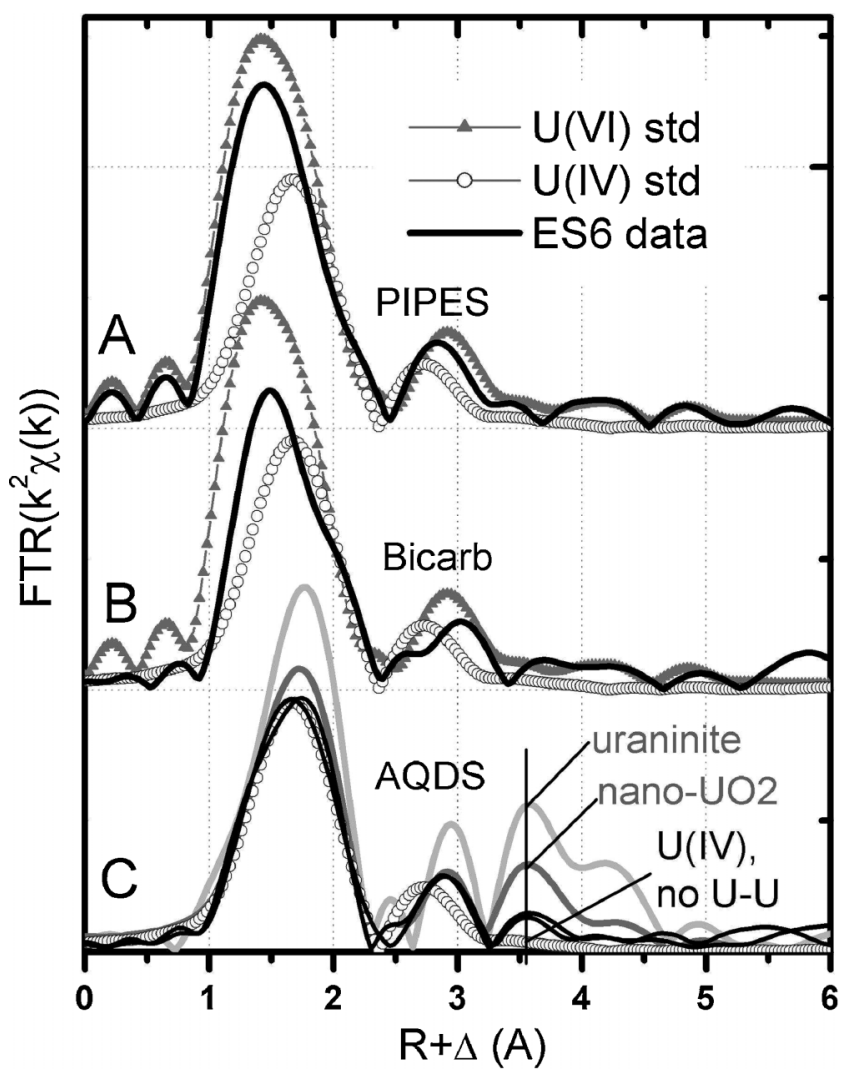

Figure 6. Fourier transformed EXAFS data from Cellulomonas ES6 samples (black lines), compared to standards: U(VI)-phosphate (triangles) and mononuclear U(IV) from Fletcher et al. (2010) (open circles). Fourier transform is over 2.0-9.7 $\AA^{-1}$. A: ES6 in PIPES, no AQDS. B: ES6 in bicarbonate, no AODS. C: ES6 with AODS, in PIPES and bicarbonate (black lines), compared to U(IV) standards: bulk uraninite (light gray), nanoparticulate uraninite from Burgos et al. (2008) (dark gray), and mononuclear U(IV) from Fletcher et al. (2010) (symbols).

uraninite produced by Shewanella in Burgos et al. (2008), which is used here as a reference. The spectra in the systems with AQDS are very similar to the spectrum from the mononuclear $\mathrm{U}(\mathrm{IV})$ product produced by Desulfitobacterium in the presence of phosphate (Fletcher et al., 2010). The EXAFS data are of insufficient quality for a detailed shell-by-shell analysis of this U(IV) phase. Linear combination fits with the U(IV) and U(VI) endmembers determined a U(IV)/U(VI) ratio of about 90:10.

The results above suggest that the presence of AQDS facilitates a more complete reduction of $U(V I)$ to $U(I V)$, whereas in the absence of AQDS partial or very little U(VI) reduction by ES6 occurs, depending on the buffer condition. The formation of the mononuclear $\mathrm{U}(\mathrm{IV})$ reduction product with AQDS is likely controlled by the presence of aqueous phosphate, as observed by Fletcher et al. (2010).

In addition to EXAFS-based estimates, relative contributions of $U$ removal from solution by precipitation with phosphate and precipitation by reduction to $U(I V)$ were estimated through mass balance calculations based on final concentrations of soluble species (Table I). For these calculations, lower soluble phosphate concentrations in treatments containing $\mathrm{U}$ relative to $\mathrm{U}$-free controls was assumed to have occurred due to the formation of U(VI)phosphate precipitates with a 1:1 stoichiometry of uranium and phosphate. Equilibrium speciation modeling using Visual Minteq indicated $\mathrm{Na}$-autunite $\left(\mathrm{NaUO}_{2} \mathrm{PO}_{4}\right)$ to be the most likely precipitate and thus equimolar amounts of uranium and phosphate were assumed to have precipitated (Table I, Column 4). The balance of U removed from solution was attributed to the production of U(IV) (Table I, Column 5). The calculated fraction of $U(I V)$ in the precipitated $U$ is shown in Column 6 of Table $I$. Although standard deviations associated with these calculations are larger than desired due to propagation of errors through mathematical operations, these calculations provide a basis for comparison across different treatments.

In PIPES buffer, the average U(IV) content of precipitates in the absence of AQDS was calculated to be $22 \%$. These values are close to those predicted by EXAFS (last column of Table I and supplementary material). In bicarbonate buffer without AQDS, mass balance estimates predicted that 34$44 \%$ of $U$ removed was due to reduction of $U(V I)$ to $U(I V)$ or due to adsorption. These values are significantly different from EXAFS estimates (last column of Table I and supplementary material) which also determined that solids in the bicarbonate system were present primarily as a nonuraninite $\mathrm{U}(\mathrm{IV})$ phase, most likely as U(IV)-phosphates. Since precipitation of phosphate with U(IV) cannot be accounted for through our mass balance approach, our mass balance-based estimates of relative $\mathrm{U}(\mathrm{VI}) / \mathrm{U}(\mathrm{IV})$ content are likely erroneous. In the presence of AQDS, mass balance calculations suggest that almost all the $U$ removed from solution in both PIPES and bicarbonate buffer was due to reduction to $U(I V)$ and are consistent with our EXAFS estimates (last column of Table I and supplementary material).

\section{TEM, HR-TEM and EDS analysis}

In addition to XAS analysis, TEM, and EDS data were obtained to support the proposed immobilization mechanisms. Figure 7 shows electron dense granules in whole cells that had not been exposed to U. Such metachromatic granules are often masses of volutin, a polymetaphosphate (Liu et al., 1996; Nester et al., 2004; Nielsen et al., 1998). Inorganic polyphosphates are usually linear polymers of phosphate residues linked by phosphoanhydride bonds (Merroun et al., 2002) with chain lengths varying between 3 and 1,000 monomeric units, depending on the organism, its growth, and other physiological conditions (van Veen et al., 1993). Polyphosphate has many biochemical functions, and can be used as an energy source and a chelator of bivalent metals ions (Keasling and Hupf, 1996). The presence of electron dense granules in ES6 and release of excessive phosphate indicates that polyphosphate is very likely the source of phosphate released by ES6. 
Table I. Estimates of U(IV) in precipitated U based on EXAFS and mass balance calculations.

\begin{tabular}{|c|c|c|c|c|c|c|}
\hline \multirow[b]{3}{*}{ Experimental conditions } & \multicolumn{5}{|c|}{ Calculations based on mass balance of soluble $\mathrm{U}(\mathrm{VI})$ and $\mathrm{PO}_{4}^{3-}$} & \multirow{3}{*}{$\begin{array}{c}\text { Calculations from } \\
\text { EXAFS measurements; } \\
\% \mathrm{U}(\mathrm{IV}) \text { of total U removed }\end{array}$} \\
\hline & \multirow[b]{2}{*}{$\begin{array}{c}\mathrm{U}(\mathrm{VI}) \\
\text { removed }(\mathrm{mM})^{\mathrm{a}}\end{array}$} & \multirow[b]{2}{*}{$\begin{array}{l}\mathrm{PO}_{4}^{3-} \text { remaining } \\
\text { in solution }(\mathrm{mM})^{\mathrm{b}}\end{array}$} & \multicolumn{2}{|c|}{$\begin{array}{l}\text { Calculated } \mathrm{U}(\mathrm{VI}) \text { removal } \\
\text { assuming precipitation } \\
\text { with } \mathrm{PO}_{4}^{3-} \text { or by } \\
\text { reduction to } \mathrm{U}(\mathrm{IV})\end{array}$} & \multirow[b]{2}{*}{$\begin{array}{c}\% \mathrm{U}(\mathrm{IV}) \text { of total } \\
\mathrm{U} \text { removed }\end{array}$} & \\
\hline & & & $\begin{array}{l}\text { Precipitation } \\
\quad(\mathrm{mM})^{\mathrm{c}}\end{array}$ & $\begin{array}{l}\text { Reduction } \\
(\mathrm{mM})^{\mathrm{d}}\end{array}$ & & \\
\hline \multicolumn{7}{|l|}{$\mathrm{CO}_{3}^{-}$buffer $-2.3 \mathrm{mg}$-cells $/ \mathrm{mL}$} \\
\hline ES6 + 0.1 mMU(VI) & $0.102 \pm 0.003$ & $0.501 \pm 0.00$ & $0.035 \pm 0.01434 .3$ & $0.035 \pm 0.014$ & $34.3 \pm 15.2$ & Not measured \\
\hline $\mathrm{ES} 6+0.25 \mathrm{mM} \mathrm{U}(\mathrm{VI})$ & $0.266 \pm 0.005$ & $60.420 \pm 0.025$ & $0.148 \pm 0.028$ & $0.118 \pm 0.028$ & $44.4 \pm 12.4$ & Not measured \\
\hline ES6 only (U-free control) & n.a. & $0.568 \pm 0.012$ & n.a. & n.a. & n.a. & n.a. \\
\hline \multicolumn{7}{|l|}{$\mathrm{HCO}_{3}^{-}$buffer- $1.15 \mathrm{mg}$-cells $/ \mathrm{mL}$} \\
\hline $\mathrm{ES} 6+0.1 \mathrm{mM} \mathrm{U}(\mathrm{VI})$ & $0.061 \pm 0.019$ & $0.291 \pm 0.002$ & $0.038 \pm 0.010$ & $0.023 \pm 0.021$ & $37.7 \pm 37.3$ & 69 \\
\hline $\mathrm{ES} 6+0.1 \mathrm{mM} \mathrm{U}(\mathrm{VI})+\mathrm{AQDS}$ & $0.097 \pm 0.003$ & $0.337 \pm 0.025$ & Not significant & $0.097 \pm 0.003$ & 100 & 88 \\
\hline ES6 only (U-free control) & n.a. & $0.330 \pm 0.010$ & n.a. & n.a. & n.a. & n.a. \\
\hline \multicolumn{7}{|l|}{ PIPES buffer-0.52 mg-cells $/ \mathrm{mL}$} \\
\hline $\mathrm{ES} 6+0.1 \mathrm{mM} \mathrm{U}(\mathrm{VI})$ & $0.089 \pm 0.002$ & $0.145 \pm 0.005$ & $0.069 \pm 0.020$ & $0.020 \pm 0.02$ & $22.4 \pm 23.5$ & 16 \\
\hline $\mathrm{ES} 6+0.1 \mathrm{mM} \mathrm{U}(\mathrm{VI})+\mathrm{AQDS}$ & $0.093 \pm 0.005$ & $0.219 \pm 0.002$ & Not significant & $0.093 \pm 0.005$ & 100 & 90 \\
\hline ES6 only (U-free control) & n.a. & $0.214 \pm 0.019$ & n.a. & n.a. & & n.a. \\
\hline
\end{tabular}

Mass balance calculations for $\mathrm{U}$ and $\mathrm{P}$ were used to determine relative amounts of uranyl phosphate and $\mathrm{U}(\mathrm{IV})$. These calculations assumed that a difference in $\mathrm{PO}_{4}^{3-}$ concentrations between treatments containing $\mathrm{U}(\mathrm{VI})$ and $\mathrm{U}$-free controls was the result of $\mathrm{U}(\mathrm{VI})$-phosphate formation. Estimates were based on measured final concentrations of soluble species $(t=295 \mathrm{~h}$ and $t=480 \mathrm{~h}$ for experiments in PIPES and bicarbonate, respectively). EXAFS calculations are based on relative content of the endmember U(VI) and U(IV) spectra in each sample's spectrum. Errors on mass balance calculations represent one standard deviation from mean values. The uncertainty in the EXAFS determinations is estimated at $10-15 \%$.

${ }^{\mathrm{a}} \mathrm{Equal}$ to the difference between initial and final $\mathrm{U}(\mathrm{VI})$ concentrations in the experiment.

${ }^{\mathrm{b}}$ Equal to the concentration of $\mathrm{PO}_{4}^{3-}$ measured in solution at the end of the experiment

${ }^{\mathrm{c} C a l c u l a t e d}$ as equal to $\mathrm{PO}_{4}^{3-}$ removed relative to $\mathrm{U}$-free control.

${ }^{\mathrm{d}}$ Calculated as balance of $\mathrm{U}$ removed after accounting for losses due to precipitation with $\mathrm{PO}_{4}^{3-}$.

Figure 8a shows intracellular U-phosphate precipitates when ES6 was exposed to U(VI) in PIPES although extracellular precipitates formed as well (Fig. 9a and b). Extracellular association of $U$ with bacterial cell surfaces is likely due to physical and chemical interactions involving adsorption and ion exchange (Francis et al., 2004). Bacterial cell walls, exopolymers, and lipids contain carboxyl, hydroxyl, amino, and phosphate groups capable of extracellular U binding (Fowle et al., 2000; Gorman-Lewis

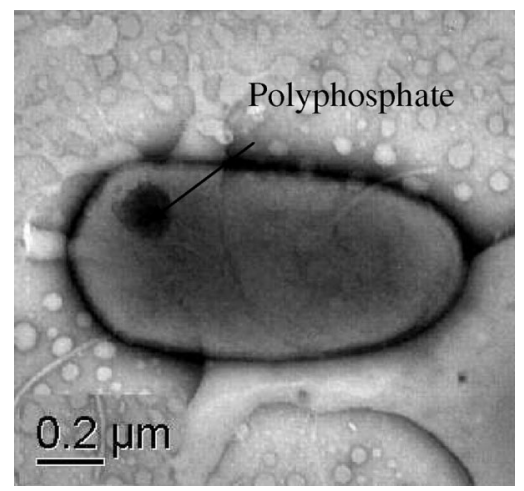

Figure 7. Transmission electron micrographs of whole cell mounts of strain ES6 showing electron-dense polyphosphate-like intracellular granules. Samples for imaging were obtained from ES6 treatments in bicarbonate buffer in the absence of AQDS. et al., 2005). However, since some $U$ precipitation also occurred within cells, it is likely that $\mathrm{U}$ was transported into cells and precipitated either as a result of enzymatic reduction or by reaction with intracellular phosphate. Andres et al. $(1993,1994)$ observed both intra- and extracellular $\mathrm{U}$ association in Mycobacterium smegmatis. Pseudomonas fluorescens accumulates $\mathrm{U}$ as fine-grained crystals in the periplasm along its plasma and outer membranes (Krueger et al., 1993). Francis et al. (2004) observed extracellular association with Bacillus subtilis, Pseudomonas fluorescens, Haloanaerobium praevalens, and Halobacterium halobium while studies with Halomonas sp. showed both extracellular and intracellular association. Figure $8 \mathrm{~b}$ shows that $\mathrm{U}(\mathrm{VI})$-phosphate precipitates formed laths $\sim 40-70 \mathrm{~nm}$ long, but only $2-5 \mathrm{~nm}$ in width, while Figure $8 \mathrm{c}$ shows the corresponding EDS spectrum. Such laths have also been reported by Marques et al. (1991) with a Pseudomonas sp. Copper peaks are the result of the copper grid used for mounting thin sections. EDS analysis confirmed the presence of $\mathrm{U}$ and $\mathrm{P}$ in these precipitates (Fig. 8c).

In addition to cell associated $\mathrm{U}$ precipitates, we observed precipitates that did not appear to be cell-associated (Fig. 9a and b). These precipitates appeared to be larger than cell-associated precipitates, but generally retained their nanometer size lath nature. The EDS spectrum also indicates the presence of both $\mathrm{U}$ and $\mathrm{P}$ (Fig. 9c). The general formula of uranylphosphate precipitates is $\mathrm{M}\left(\mathrm{UO}_{2} \mathrm{PO}_{4}\right)_{n} \cdot \mathrm{mH}_{2} \mathrm{O}$ in 


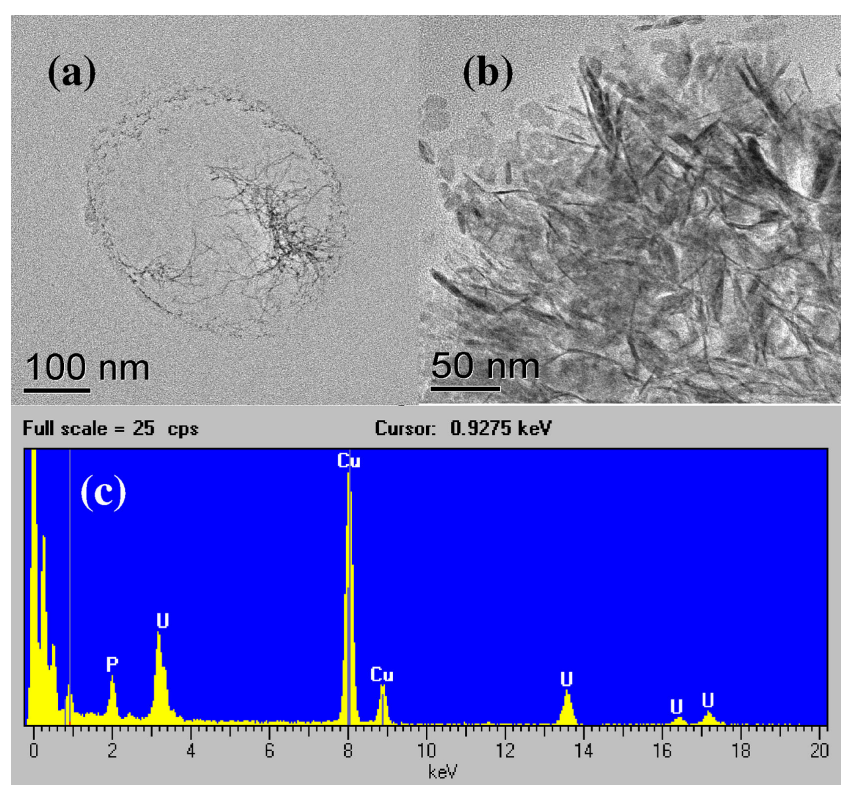

Figure 8. Transmission electron micrograph of thin section of strain ES6 cells challenged with uranium in PIPES buffer without AODS (a). b: Nanometer size, lath like uranylphosphate precipitates. c: EDS spectrum of cell associated precipitates. Copper peak is from the grid. [Color figure can be seen in the online version of this article, available at wileyonlinelibrary.com.]

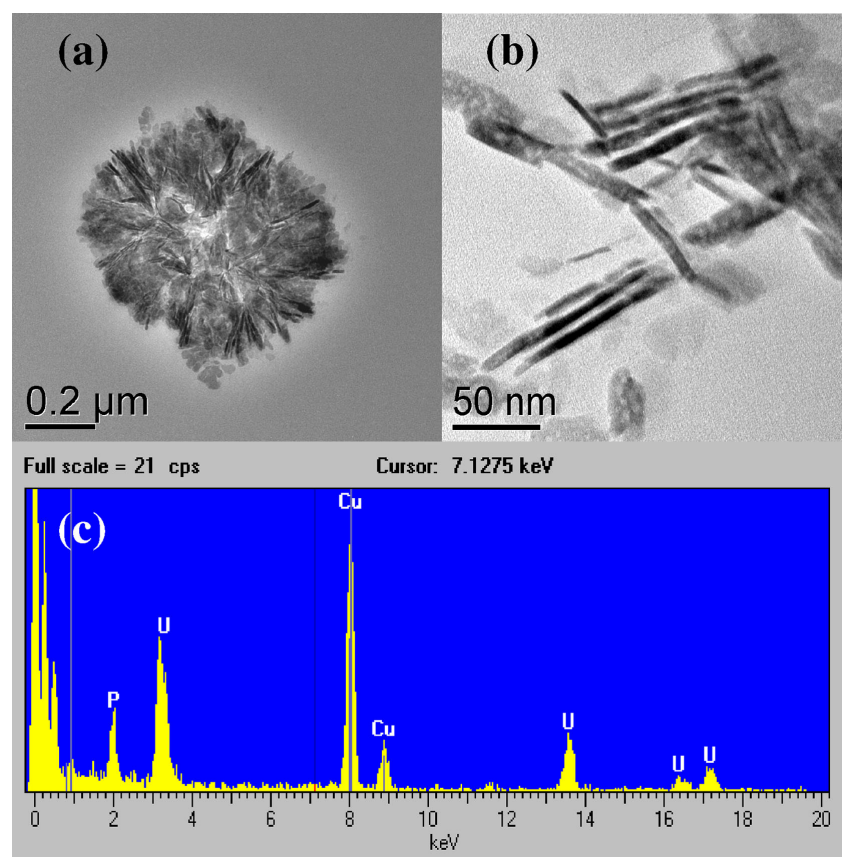

Figure 9. a and $\mathbf{b}$ : Transmission electron micrograph of uranylphosphate precipitates. c: EDS spectrum of uranylphosphate precipitates. Copper peak is from the grid. Samples for imaging were obtained from ES6 treatments with U(VI) in PIPES buffer in the absence of AODS. [Color figure can be seen in the online version of this article, available at wileyonlinelibrary.com.] which M may be mono or divalent cations and $n$ may be 1 or 2 depending on the valence state of the metal cation. Based on the Minteq modeling, Na-autunite is the most likely mineral phase to precipitate. Autunites have been described to have a typical structure of negatively charged layers of $\left(\mathrm{UO}_{2} \mathrm{PO}_{4}\right) n$ separated by staggered layers of water molecules and compensating cations (Yong and Macaskie, 1995).

The results presented here are the first report of an environmentally relevant subsurface microorganism capable of $\mathrm{U}$ immobilization by two different mechanisms (reductive precipitation or precipitation with biogenic phosphate ligands) depending on the environmental conditions. Polyphosphate accumulation and release is generally related to cellular energetics for survival and growth. In ES6, it may be also serving as a detoxification mechanism, as proposed recently for the hydrolysis of exogenous organophosphate compounds with other microorganisms (Beazley et al., 2007, 2009). Adsorption of U(VI) to cell surfaces might have also occurred, but was not independently verified in this study. Overall, our results offer a first step toward understanding and quantifying the phosphate release and U removal by Cellulomonas sp. strain ES6. This work demonstrates a potential role for Gram-positive fermentative organisms, represented here by the genus Cellulomonas, in metals biotransformation in the environment. The ability of Cellulomonas sp. to reduce $\mathrm{Cr}(\mathrm{VI})$ to $\mathrm{Cr}$ (III) (Sani et al., 2002; Viamajala et al., 2007, 2008) and to precipitate $\mathrm{U}$ as $\mathrm{U}(\mathrm{IV})$ and $\mathrm{U}(\mathrm{VI})$-phosphate indicates a potential long-term application of in situ heavy metal and radionuclide removal.

\footnotetext{
We thank Chris Davitt, Valerie Lynch of the Electron Microscopy Center, Washington State University for TEM images. We also thank Pacific Northwest National Laboratory-Environmental Molecular Sciences Laboratory for HR-TEM analyses. Research was supported by the U.S. Department of Energy, Office of Science, Environmental Management Science Program under Grant No. DE-FG0203ER63582 and DOE-NE Idaho Operations Office Contract DEAC07-05ID14517. Research was also supported by the Inland Northwest Research Alliance under contract WSU 005 and a National Science Foundation (NSF) CAREER Award (EAR 0847683 to Thomas Borch). Funding for Ken Kemner and Maxim Boyanov was provided under the Argonne Subsurface Science Focus Area grant by the U.S. Department of Energy's Office of Science (DOE-SC), Office of Biological and Environmental Research, Subsurface Biogeochemical Research Program. Portions of this work were performed at GeoSoilEnviroCARS (Sector 13), Advanced Photon Source (APS), Argonne National Laboratory. GeoSoilEnviroCARS is supported by the National Science Foundation-Earth Sciences (EAR-0622171) and Department of Energy-Geosciences (DE-FG02-94ER14466). Use of the Advanced Photon Source was supported by the U.S. Department of Energy, Office of Science, Office of Basic Energy Sciences, under Contract No. DE-AC02-06CH11357.
}

\section{References}

Anderson RT, Vrionis HA, Ortiz-Bernad I, Resch CT, Long PE, Dayvault R, Karp K, Marutzky S, Metzler DR, Peacock A, White DC, Lowe M, Lovley DR. 2003. Stimulating the in situ activity of Geobacter species to 
remove uranium from the groundwater of a uranium-contaminated aquifer. Appl Environ Microbiol 69:5884-5891.

Andres Y, MacCordick J, Hubert JC. 1993. Adsorption of several actinide (TH, U) and lanthanide (LA, EU, YB) ions by Mycobacterium smegmatis. Appl Microbiol Biotechnol 39:413-417.

Andres Y, MacCordick J, Hubert JC. 1994. Binding sites of sorbed uranyl ion in the cell wall of Mycobacterium smegmatis. FEMS Microbiol Lett 115:27-32.

Arey JS, Seaman JC, Bertsch PM. 1999. Immobilization of uranium in contaminated sediments by hydroxyapatite addition. Environ Sci Technol 33:337-342.

Beazley MJ, Martinez RJ, Sobecky PA, Webb SM, Taillefert M. 2007. Uranium biomineralization as a result of bacterial phosphatase activity: Insights from bacterial isolates from a contaminated subsurface. Environ Sci Technol 41:5701-5707.

Beazley MJ, Martinez RJ, Sobecky PA, Webb SM, Taillefert M. 2009. Nonreductive biomineralization of uranium(VI) phosphate via microbial phosphatase activity in anaerobic conditions. Geomicrobiol J 26: 431-441.

Benz M, Schink B, Brune A. 1998. Humic acid reduction by Propiionibacterium freudenreichii and other fermenting bacteria. Appl Environ Microbiol 64:4507-4512.

Bertsch PM, Hunter DB, Sutton SR, Bajt S, Rivers ML. 1994. In situ chemical speciation of uranium in soils and sediments by micro $\mathrm{x}$ ray adsorption spectroscopy. Environ Sci Technol 28:980-984.

Borch T, Inskeep WP, Harwood JA, Gerlach R. 2005. Impact of ferrihydrite and anthraquinone-2,6-disulfonate on the reductive transformation of 2,4,6-trinitrotoluene by a Gram-positive fermenting bacterium. Environ Sci Technol 39:7126-7133.

Borch T, Masue Y, Kukkadapu RK, Fendorf S. 2007. Phosphate imposed limitations on biological reduction and alteration of ferrihydrite. Environ Sci Technol 41:166-172.

Borch T, Kretzschmar R, Kappler A, Cappellen PV, Ginder-Vogel M, Voegelin A, Campbell K. 2010. Biogeochemical redox processes and their impact on contaminant dynamics. Environ Sci Technol 44:15-23.

Boswell CD, Hewitt CJ, Macaskie LE. 1998. An application of bacterial flow cytometry-Evaluation of the toxic effects of four heavy metals on Acinetobacter sp. with potential for bioremediation of contaminated waste waters. Biotechnol Lett 20:857-863.

Boswell CD, Dick RE, Macaskie LE. 1999. The effect of heavy metals and other environmental conditions on anaerobic phosphate metabolism of Acinetobacter johnsonii. Microbiology 145:1711-1720.

Boyanov MI, O’Loughlin EJ, Roden EE, Fein JB, Kemner KM. 2007. Adsorption of $\mathrm{Fe}(\mathrm{II})$ and $\mathrm{U}(\mathrm{VI})$ to carboxyl-functionalized microspheres: The influence of speciation on uranyl reduction studied by titration and XAFS. Geochim Cosmochim Acta 71(8):1898-1912.

Brina R, Miller AG. 1992. Direct detection of trace levels of uranium by laser induced kinetic phosphoremeter. Anal Chem 64:1415-1418.

Burgos WD, McDonough JT, Senko JM, Zhang GX, Dohnalkova AC, Kelly SD, Gorby Y, Kemner KM. 2008. Characterization of uraninite nanoparticles produced by Shewanella oneidensis MR-1. Geochim Cosmochim Acta 72(20):4901-4915.

Duerden P. 1990. Alligator river analogue project, 1st Annual Report 1988-89, Australian Nuclear Science and Technology Organization (ANSTO).

Emsley J. 1989. The elements. New York, NY: Oxford University Press. p. 202.

Fletcher K, Boyanov MI, Kemner KK, Thomas SH, Wu Q, Loeffler F. 2010. $\mathrm{U}(\mathrm{VI})$ reduction to mononuclear $\mathrm{U}(\mathrm{IV})$ by Desulfitobacterium spp. Environ Sci Technol 44:4705-4709.

Fowle DA, Fein JB, Martin AM. 2000. Experimental study of urany adsorption onto Bacillus subtilis. Environ Sci Technol 34:3737-3741.

Francis AJ, Gillow JB, Dodge CJ, Harris R, Beveridge TJ, Papenguth HW. 2004. Uranium association with halophilic and non-halophilic bacteria and archaea. Radiochim Acta 98:1-8.

Fredrickson JK, Kostandarithes HM, Li SW, Plymale AE, Daly MJ. 2000a. Reduction of $\mathrm{Fe}(\mathrm{III}), \mathrm{Cr}(\mathrm{VI}), \mathrm{U}(\mathrm{VI})$ and $\mathrm{Tc}(\mathrm{VII})$ by Deinococus radiodurans R1. Appl Environ Microbiol 66:2006-2011.
Fredrickson JK, Zachara JM, Kennedy DW, Duff MC, Gorby YA, Li SW, Krupka KM. 2000b. Reduction of $\mathrm{U}(\mathrm{VI})$ in goethite $(\alpha-\mathrm{FeOOH})$ suspensions by a dissimilatory metal-reducing bacterium. Geochim Cosmochim Acta 64:3085-3098.

Fuller CC, Bargar JR, Davis JA, Piana MJ. 2002. Mechanisms of uranium interactions with hydroxyapatite: Implications for ground water remediation. Environ Sci Technol 36:58-65.

Gerhardt P, Murray RGE, Costilow RN, Nester EW, Wood WA, Krieg NR, Phillips GB. 1981. Manual of methods for general bacteriology. Am Soc Microbiol 505.

Gorby YA, Lovley DR. 1992. Enzymatic uranium precipitation. Environ Sci Technol 26:205-207.

Gorman-Lewis D, Elias PE, Fein JB. 2005. Adsorption of aqueous uranyl complexes onto Bacillus subtilis cells. Environ Sci Technol 39:49064912.

Gounot AM. 1994. Microbial oxidation and reduction of manganese: Consequences in groundwater and applications. FEMS Microbiol Rev 14:339-349.

Groenestijn JW, Deinema MH, Zehnder AJB. 1987. ATP production from polyphosphate in Acinetobacter strain 210A. Arch Microbiol 148:14-19.

Groenestijn JW, Bentvelsen MMA, Deinema MH, Zehnder AJB. 1988. Polyphosphate-degrading enzymes in Acinetobacter spp. And activated sludge. Appl Environ Microbiol 55:219-223.

Gu B, Yan H, Zhou P, Watson DB, Park M, Istok J. 2005. Natural humics impact uranium bioreduction and oxidation. Environ Sci Technol 39:5268-5275.

Jerden JL, Sinha AK. 2003. Phosphate based immobilization of uranium in an oxidizing bedrock aquifer. Appl Geochem 18:823-843.

Keasling JD, Hupf GA. 1996. Genetic manipulation of polyphosphate metabolism affects cadmium tolerance in Escherichia coli. Appl Environ Microbiol 62:743-746.

Khijniak TV, Slobodkin AI, Coker V, Renshaw JC, Livens FR, BonchOsmolovskaya EA, Birkeland NK, Medvedeva-Lyalikova NN, Lloyd JR. 2005. Reduction of uranium(VI) phosphate during growth of the thermophilic bacterium Thermoterrabacterium ferrireducens. Appl Environ Microbiol 71(10): 6423-6426.

Kim KW, Kim YH, Lee SY, Lee JW, Joe KS, Lee EH, Kim JS, Song K, Song KC. 2009. Precipitation characteristics of uranyl ions at different $\mathrm{pHs}$ depending on the presence of carbonate ions and hydrogen peroxide. Environ Sci Technol 43:2355-2361.

Knopp R, Panak PJ, Wray LA, Renninger NS, Keasling JD, Nitsche H. 2003. Laser spectroscopic studies of interactions of UVI with bacterial phosphate species. Chem Eur J 9:2812-2818.

Krueger S, Olsen GJ, Johnsonbaugh D, Beveridge TJ. 1993. Characterization of the binding of gallium, platinum, and uranium to pseudomonas fluorescens by small-angle X-ray scattering and transmission electron microscopy. Appl Environ Microbiol 59:4056-4064.

Liu W, Nakamura K, Matsuo T, Mino T. 1996. Internal energy-based competition between polyphosphate- and glycogen-accumulating bacteria in biological phosphorus removal reactors - Effect of $\mathrm{P} / \mathrm{C}$ feeding ration. Water Res 31:1430-1438.

Lloyd JR, Renshaw JC, May I, Livens FR, Burke IT, Mortimerc RJG, Morris K. 2005. Biotransformation of radioactive waste: Microbial reduction of actinides and fission products. J Nucl Radiochem Sci 6:17-20.

Lovley DR, Phillips JP. 1992. Reduction of uranium by Desulfovibrio desulfuricans. Appl Environ Microbiol 58:850-856.

Lovley DR, Phillips EJP, Gorby YA, Landa ER. 1991. Microbial reduction of uranium. Nature 350:413-416.

Lovley DR, Coates JD, Blunt-Harris EL, Phillips EJ, Woodward JC. 1996. Humic substances as electron acceptors for microbial respiration. Nature 382:445-448.

Lovley DR, Fraga JL, Blunt-Harris EL, Hayes LA, Phillips EJP, Coates JD. 1998. Humic substances as a mediator for microbially catalyzed metal reduction. Acta Hydrochim Hydrobiol 26:152-157.

Macaskie L, Bonthrone KM, Rouch DA. 1994. Phosphatase-mediated heavy metal accumulation by a Citrobacter sp. and related enterobacteria. FEMS Microbiol Lett 121:141-146. 
Malekzadeh F, Farazmand A, Ghafmrian H, Shahamat M, Levin M, Colwell RR. 2002. Uranium accumulation by a bacterium isolated from electroplating effluent. World J Microbiol Biotechnol 18:295-302.

Marques AM, Roca X, Simon-Pujol MD, Fuste MC, Congregado F. 1991. Uranium accumulation by Pseudomonas sp. EPS-5028. Appl Microbiol Biotechnol 35:406-410.

Martinez RJ, Beazley MJ, Taillefert M, Arakaki AK, Skolnick J, Sobecky PA. 2007. Aerobic uranium (VI) bioprecipitation by metal-resistant bacteria isolated from radionuclide- and metal-contaminated subsurface soils. Environ Microbiol 9:3122-3133.

Merroun ML, Selenska-Pobell S. 2008. Bacterial interactions with uranium: An environmental perspective. J Cont Hydrol 102:285-295.

Merroun ML, Hennig C, Rossberg A, Geipel G, Reich T, Selenska-Pobell S. 2002. Molecular and atomic analysis of uranium complexes formed by three eco-types of Acidithiobacillus ferrooxidans. Proceedings in Biometals 2002: Bioremediation, Biochemical Society Transactions 30: 669-672.

Merroun ML, Hennig C, Rossberg A, Reich T, Selenska-Pobell S. 2003. Characterization of $\mathrm{U}$ (VI)-Acidithiobacillus ferrooxidans complexes by using EXAFS, transmission electron microscopy and energy-dispersive X-ray analysis. Radiochim Acta 91:583-591.

Merroun ML, Raff J, Rossberg A, Hennig C, Reich T, Selenska-Pobell S. 2005. Complexation of uranium by cells and S-layer sheets of Bacillus sphaericus JG-A12. Appl Environ Microbiol 71:5542-5553.

Montgomery DM, Dean ACR, Wiffen P, Macaskie LE. 1995. Phosphatase production and activity in Citrobacter freundii and a naturally occurring, heavy-metal-accumulating Citrobacter sp. Microbiology 141:2433-2441.

Naftz DL, Morrison SJ, Feltcorn EM, Freethey GW, Fuller CC, Piana MJ, Wilhelm RG, Rowland RC, Davis JA, Blue JE. 2000. Field demonstration of permeable reactive barriers to remove dissolved uranium from groundwater, Fry Canyon, Utah. Interim Report, EPA, USGS, EPA 402C-00-001, published on web: www.epa.gov.

Nakajima A, Sakaguchi T. 1986. Selective accumulation of heavy metals by microorganisms. Appl Microbiol Biotechnol 24:59-64.

National Research Council. 2000. Research needs in subsurface science. National Academy Press. Washington, DC.

Nester EW, Anderson DG, Roberts CE, Jr., Pearsall NN, Nester MT. 2004. Microbiology: A human perspective. 4th edition. New York, NY: McGraw Hill. p. 67.

Newville M, Livins P, Yacoby Y, Rehr JJ, Stern EA. 1993. Near-edge X-ray absorption fine structure of $\mathrm{Pb}-\mathrm{A}$ comparison of theory and experiment. Phys Rev B 47(21): 14126-14131.

Nielsen AT, Liu W, Filipe C, Grady L, Jr., Molin S, Stahl D. 1998. Identification of a novel group of bacteria in slude from a deteriorated biological phosphorus removal reactor. Appl Environ Microbiol 65: 1251-1258.

Palie PN. 1970. Analytical chemistry of uranium. Ann Arbor: Humphrey Science Publishers, Inc. (Translated by Kaner N).

Panak PJ, Raff J, Selenska-Pobell S, Geipel G, Bernhard G, Nitsche H. 2000. Complex formation of $\mathrm{U}(\mathrm{VI})$ with Bacillus-isolaes from a uranium mining waste pile. Radiochem Acta 88:71-76.

Ravel B, Newville M. 2005. Athena, artemis, hephaestus: Data analysis for $\mathrm{X}$-ray absorption spectroscopy using IFEFFIT. J Synchrotron Radiat 12:537-541.

Riley RG, Zachara JM, Wobber FJ. 1992. Chemical contaminants on DOE lands and selection of contaminant mixtures for subsurface research. DOE/ER-0547T, United State Department of Energy, Washington, DC.

Sani RK, Peyton BM, Smith WA, Apel WA, Petersen JN. 2002. Dissimilatory reduction of $\mathrm{Cr}(\mathrm{VI}), \mathrm{Fe}(\mathrm{III})$, and $\mathrm{U}(\mathrm{VI})$ by Cellulomonas isolates. Appl Microbiol Biotechnol 60:192-199.
Scott MJ, Morgan JJ. 1990. Energetics and conservative properties of redox systems. Chem Modeling of Aqueous Systems II. Chap. 29:368-378 (Am Chem Soc).

Segre CU, Leyarovska NE, Chapman LD, Lavender WM, Plag PW, King AS, Kropf AJ, Bunker BA, Kemner KM, Dutta P, Duran RS, Kaduk J. 2000. The MRCAT insertion device beamline at the advanced photon source. In: Pianetta $P$, editor. Synchrotron radiation instrumentation: Eleventh U.S. National Conference. New York: American Institute of Physics. pp. 419-422.

Spear JR, Figueroa LA, Honeyman BD. 1999. Modeling the removal of uranium $\mathrm{U}(\mathrm{VI})$ from aqueous solutions in the presence of sulfate reducing bacteria. Environ Sci Technol 33:2667-2675.

Spear JR, Figueroa LA, Honeyman BD. 2000. Modeling reduction of uranium $\mathrm{U}(\mathrm{VI})$ under variable sulfate concentrations by sulfate-reducing bacteria. Appl Environ Microbiol 66:3711-3721.

Stewart BD, Mayes MA, Fendorf S. 2010. Impact of uranyl-calciumcarbonato complexes on uranium(VI) adsorption to synthetic and natural sediments. Environ Sci Technol 44:928-934.

Strandberg GW, Shumate SE II, Parrott JR, Jr. 1981. Microbial cells as biosorbents for heavy metals: Accumulation of uranium by Saccharomyces cerevisiae and Pseudomonas aeruginosa. Appl Environ Microbiol 41:237-245.

Suzuki Y, Banfield J. 2004. Resistance to, and accumulation of, uranium by bacteria from a uranium-contaminated site. Geomicrobiol J 21:113121.

Suzuki Y, Kelly SD, Kemner KM, Banfield JF. 2002. Radionuclide contamination-Nanometre-size products of uranium bioreduction. Nature 419(6903):134-134.

Tandoi V, Majone M, May J, Ramadori R. 1998. The behavior of polyphosphate accumulating Acinetobacter isolates in an anaerobic-aerobic chemostat. Water Res 32:2903-2912.

Twigg RS. 1945. Oxidation-reduction aspects of resazurin. Nature 155:401402.

Van Veen HW, Abee T, Kortstee GJJ, Konings WN, Zehnder AJB. 1993. Characterization of two phosphate transport systems in Acinetobacter johnsonii 210A. J Bacteriol 175:200-206.

Viamajala S, Smith WA, Sani RK, Apel WA, Petersen JN, Neal AL, Roberto FF, Newby DT, Peyton BM. 2007. Isolation and characterization of $\mathrm{Cr}(\mathrm{VI})$ reducing Cellulomonas spp. from subsurface soils: Implications for long term chromate reduction. Bioresource Technol 98: 612-622.

Viamajala S, Peyton BM, Gerlach R, Sivaswamy V, Apel WA, Petersen JN. 2008. Permeable reactive biobarriers for in situ $\mathrm{Cr}(\mathrm{VI})$ reduction: Bench scale tests using Cellulomonas sp. strain ES6. Biotech Bioeng 101:1150-1162.

Watts RJ. 1997. Hazardous wastes: Sources, pathways, receptors. Hoboken, NJ: John Wiley \& Sons, Inc., p. 265.

Yong P, Macaskie LE. 1995. Enhancement of uranium bioaccumulation by a Citrobacter sp. via enzymatically-mediated growth of polycrystalline $\mathrm{NH}_{4} \mathrm{UO}_{2} \mathrm{PO}_{4}$. J Chem Tech Biotechnol 63:101-108.

Yong P, Macaskie LE. 1998. Bioaccumulation of lanthanum, uranium and thorium, and use of a model system to develop a method for the biologically-mediated removal of plutonium from solution. J Chem Technol Biotechnol 71:15-26.

Zafiri C, Kornaros K, Lyberatos G. 1999. Kinetic modeling of biological phosphorus removal with a pure culture of Acinetobacter sp. under aerobic, anaerobic and transient operating conditions. Water Res 33: 2769-2788.

Zehnder AJB, Stumm W. 1988. Geochemistry and biogeochemistry of anaerobic habitats. Biology of anaerobic microorganisms. Hoboken, NJ: John Wiley and Sons. pp. 1-38. 